\title{
Facklamia hominis pyelonephritis in a pediatric patient: first case report and review of the literature
}

\author{
Samantha Pérez-Cavazos ${ }^{1} \mathbb{B}$, Daniela Cisneros-Saldaña ${ }^{1} \mathbb{D}$, Fernando Espinosa-Villaseñor ${ }^{1} \mathbb{B}$, \\ José Iván Castillo-Bejarano ${ }^{1} \mathbb{0}$, Denisse Natalie Vaquera-Aparicio ${ }^{1} \mathbb{0}$, Hugo Sánchez-Alanís ${ }^{2}$ [D and \\ Abiel Mascareñas-De los Santos ${ }^{1^{*}}$ D
}

\begin{abstract}
Background: Pyelonephritis is one of the most serious bacterial illnesses during childhood. Gram-negative organisms account for up to $90 \%$ of the cases. Gram-positive bacteria are uncommon causes of urinary tract infections, and only a few cases caused by Facklamia hominis have been reported in the literature.

Case presentation: A five-year-old girl with tracheostomy and gastrostomy and past medical history of congenital lymphangioma presented with a two-week history of with intermittent fever, frequent urination, and vesical tenesmus. Diagnosis of pyelonephritis was made. Urine culture reported colonies with alpha-hemolysis in blood agar at 48-h of incubation and Facklamia hominis was identified by MALDI-TOF. The patient was successfully treated with gentamicin.

Conclusions: This is the first reported case of pyelonephritis by Facklamia hominis in a child, and the second involving infection in a pediatric patient. Although this pathogen is uncommon, current treatment of F. hominis is a challenge for physicians. This case illustrates the requirement to standardize identification and treatment of care to avoid treatment failure and antimicrobial resistance.
\end{abstract}

Keywords: Facklamia hominis, Urinary tract infection, Emerging pathogen, Child, Children, Pediatric

\section{Background}

Acute pyelonephritis is an infection that affects renal parenchyma and in children, it represents one of the most common causes of serious bacterial illnesses. 80-90\% of cases are caused by Escherichia coli, and the remaining $10-20 \%$ by other Gram-negative bacilli, such as Klebsiella, Enterobacter, Proteus, and Pseudomonas species, and certain Gram-positive organisms such as

\footnotetext{
*Correspondence: a_mascarenas@gmail.com

1 Department of Pediatrics / Infectious Diseases Service, Hospital Universitario "Dr. José Eleuterio González" Universidad Autónoma de Nuevo León, Francisco I. Madero Avenue, Mitras Centro, ZC 64460 Monterrey, Mexico

Full list of author information is available at the end of the article
}

Enterococcus faecalis, Staphylococcus saprophyticus, and Streptococcus agalactiae $[1,2]$.

Facklamia species are rarely involved in human infections. These Gram-negative cocci are alfa-hemolytic, catalase negative, and facultatively anaerobic [3-7]. From six members of this genus, only four (F. hominis, F. sourekii, F. ignava, and F. languida) have been identified in human clinical specimens, causing a range of illnesses such as sepsis, bacteremia, abscesses, peritonitis, meningitis, endocarditis, genitourinary infection, chorioamnionitis, and prosthetic joint infection [3-6]. Facklamia hominis is the most common member of this genus involved in human infection [3]. We present the first reported case of pyelonephritis caused by Facklamia hominis in a child. original author(s) and the source, provide a link to the Creative Commons licence, and indicate if changes were made. The images or other third party material in this article are included in the article's Creative Commons licence, unless indicated otherwise in a credit line to the material. If material is not included in the article's Creative Commons licence and your intended use is not permitted by statutory regulation or exceeds the permitted use, you will need to obtain permission directly from the copyright holder. To view a copy of this licence, visit http://creativecommons.org/licenses/by/4.0/. The Creative Commons Public Domain Dedication waiver (http://creativeco mmons.org/publicdomain/zero/1.0/) applies to the data made available in this article, unless otherwise stated in a credit line to the data. 


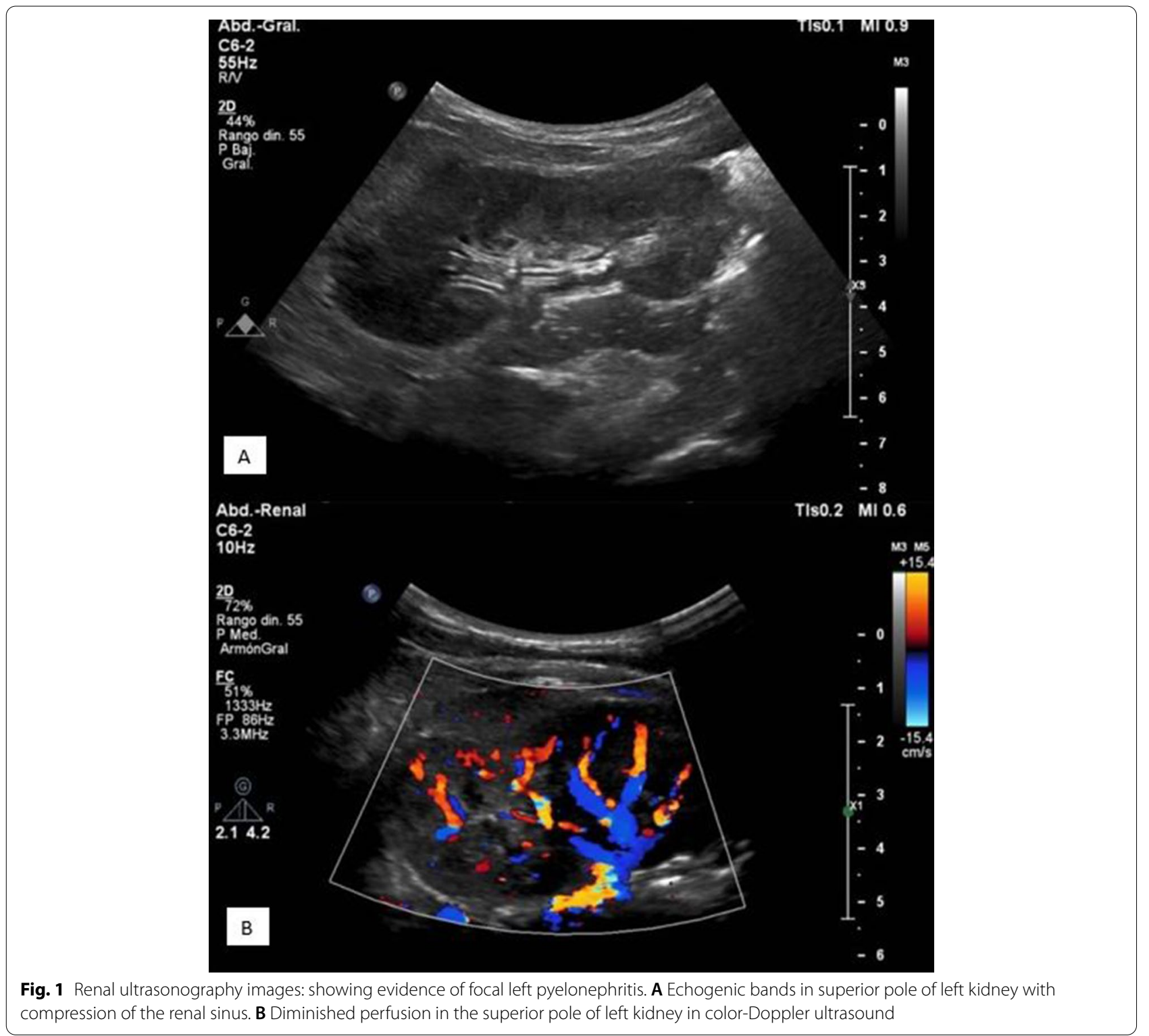

\section{Case presentation}

We present the case of a 5-year-old girl from Mexico, with medical history of a congenital cervical lymphangioma, with a partial surgical resection during the neonatal period, requiring a gastrostomy and tracheostomy, and currently being treated with oral sirolimus $\left(0.8 \mathrm{mg} / \mathrm{m}^{2} /\right.$ twice a day). She presented to the emergency department with a two-week history of intermittent fever, increased urination frequency, and vesical tenesmus, for which she was treated in an out-patient clinic with levofloxacin for seven days with no clinical response. Upon physical examination she had mild abdominal tenderness and left costovertebral angle tenderness. Complete blood count (CBC) was normal (leukocytes $6.25 \mathrm{k} / \mu \mathrm{L}$, neutrophils
$3.1 \mathrm{k} / \mu \mathrm{L}$, lymphocytes $2.3 \mathrm{k} / \mu \mathrm{L}$, hemoglobin $12.6 \mathrm{~g} / \mathrm{dL}$, and platelets $249,000 / \mathrm{mm} 3)$. Acute phase reactants were slightly elevated (C-reactive protein $1.1 \mathrm{mg} / \mathrm{dL}$, erythrocyte sedimentation rate $30 \mathrm{~mm} / \mathrm{h}$ ). Urinalysis was normal (negative nitrites, leukocyte esterase, and no leukocytes). Renal ultrasound showed a normal right kidney, and echogenic bands in the superior pole of the left kidney, in addition to renal sinus compression, and areas of cortical hypoperfusion in color-Doppler examination, suggestive of focal left pyelonephritis (Fig. 1). Blood and urine cultures were taken upon admission, the latter obtained via vesical catheterization. Given that the patient had no history of recent hospitalization, intravenous gentamicin $(6 \mathrm{mg} / \mathrm{kg} /$ day $)$ was empirically initiated as a second line 
of treatment for community-acquired pyelonephritis. Blood cultures were negative. After a 48-h incubation period, urine culture reported growth of colonies with alpha-hemolysis on blood agar (>100,000 CFU/mL) (Fig. 2). Colonies were identified as Facklamia hominis by a MALDI-TOF Biotyper ${ }^{\circledR}$ using a matrix-assisted laser desorption/ionization and time-of-flight (MALDITOF) mass spectrometry system, with a score value of 2.03. Antimicrobial susceptibility was determined via disc method, and the four antibiotics tested (vancomycin, gentamicin, tetracycline, linezolid) were susceptible. Quinolones were not available in laboratory. The patient presented clinical resolution of symptoms within $72 \mathrm{~h}$ of therapy. Due to the rarity of the case, a follow-up urine culture was performed 14-day later, with no growth reported, and she was discharged after completing a two week-course of gentamicin.

\section{Discussion and conclusions}

The genus Facklamia was first described in 1997 by Collins et al., using comparative $16 \mathrm{~S}$ recombinant ribonucleic acid (rRNA) gene sequencing studies, and it currently comprises six species: $F$. ignava, F. sourekii, $F$. tabaciasalis, F. languida, F. miroungii and F. hominis [4, 6, 8]. Only F. tabaciasalis and F. miroungii have not been isolated from human specimens [3, 8]. Recently, a novel species, Facklamia lactis sp. nov. was isolated from a German bulk tank milk [9].

The natural habitat of Facklamia species remains unknown, however strains associated to human infection

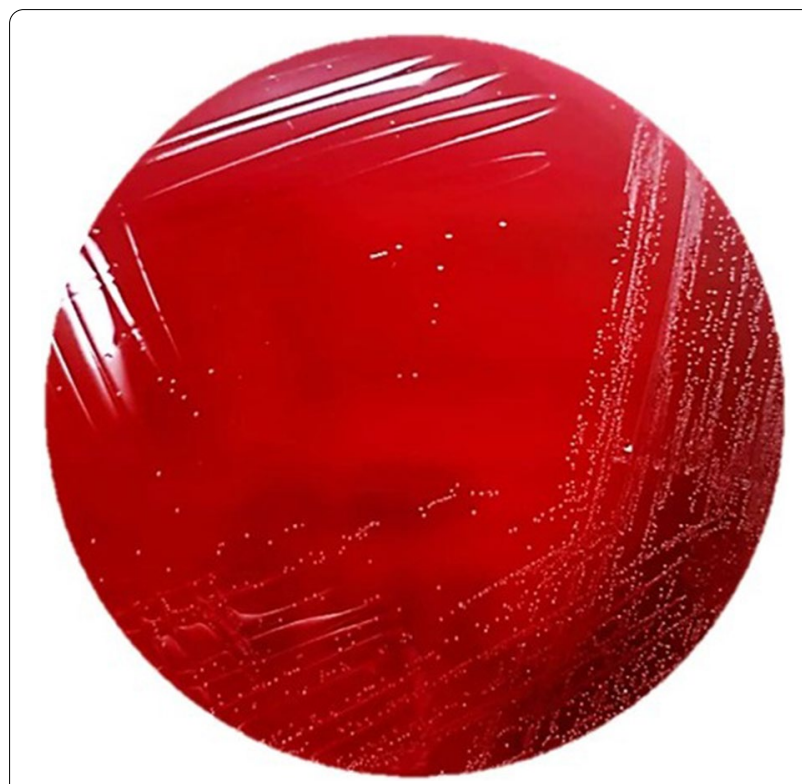

Fig. 2 Urine culture: Alpha-hemolytic, non-pigmented colonies in 5\% blood sheep agar, after a 48-h incubation period seem to be rare members of commensal microbiota of skin, and the female genitourinary tract [8]. Facklamia species are uncommon human pathogens, and since the description of the genus, very few cases of Facklamia spp human infections have been reported in medical literature $[3,7,10]$. The pathogenic potential and virulence of this genus is yet to be dilucidated [7].

F. hominis has been isolated from several clinical specimens such as urine, vagina, blood, abscesses, synovial fluid, mitral valves, placentas, gastric aspirates, cerebrospinal fluid, and preputial swabs $[6-8,10-14]$.

In this case, our patient presented with pyelonephritis and inadequate clinical response to initial treatment with quinolones. Normal findings in $\mathrm{CBC}$ and the moderate elevation in acute phase reactants could be explained either by the immunosuppressive properties of sirolimus, or due to a partial response to levofloxacin. However, therapy failure cannot be adjudicated to resistance to levofloxacin, as its susceptibility was not tested in the urine isolate due to routine laboratory protocols. In this case it could not be determined if $F$. hominis was part of the vaginal microbiota of the child, as vaginal cultures were not performed upon admission or after treatment, nonetheless follow-up urine cultures were negative.

The role of sirolimus or other immunosuppressive agents in the pathogenicity of Facklamia infections is unknown. Sirolimus has been associated with a higher rate of mucosal herpes simplex virus infections, however that association has not been observed with other pathogens such as cytomegalovirus and hepatitis $\mathrm{C}$; also it has been documented to have antifungal-activity in vitro, as it inhibits the growth of some species such as Cryptococcus neoformans, Candida albicans and Aspergillus fumigatus [15].

We performed a literature search in four languages (spanish, english, german and korean) of core databases including MEDLINE (National Library of Medicine, Bethesda, MD), SciELO (Scientific Electronic Library Online), Google Scholar (Palo Alto, California) and Web of Science (Clarivate Analytics, Philadelphia, Pennsylvania), between 1990 and 2021 using the keywords: "Facklamia spp", "Facklamia species" "F. hominis", "F. languida", "F. ignava", "F. sourekii", "F. miroungii" and "F. tabaciasalis" to identify case reports and case series. References of the selected publications were reviewed to recognize duplicate reports on case series. Twelve cases of infections due to $F$. hominis were identified. A summary of demographic and clinical data, including risk factors and treatment is available in Table 1.

Facklamia species are Gram-positive, catalase-negative, facultative anaerobic cocci, and its identification with traditional microbiologic tests can represent a challenge. Depending on species and growth conditions, they 
Table 1 Summary of Facklamia hominis infection risk factors, diagnostic methods, and treatment

\begin{tabular}{|c|c|c|c|c|c|c|}
\hline Pub year/Place & Gender/Age & $\begin{array}{l}\text { Underlying } \\
\text { condition }\end{array}$ & Infection & Sample & $\begin{array}{l}\text { Identification } \\
\text { Method }\end{array}$ & $\begin{array}{l}\text { Provided antibiotic } \\
\text { treatment }\end{array}$ \\
\hline 2004, UK [10] & F/ $34 Y$ & Pregnancy & $\begin{array}{l}\text { Chorioamnionitis } \\
\text { and puerperal bac- } \\
\text { teremia }\end{array}$ & $\begin{array}{l}\text { Placental tissue } \\
\text { swabs and placental } \\
\text { tissue }\end{array}$ & ND & $\begin{array}{l}\text { Amoxicillin and clavu- } \\
\text { lanic acid } \\
\text { Metronidazole }\end{array}$ \\
\hline $\begin{array}{l}\text { 2010, UK } \\
{[11]}\end{array}$ & ND/ND & Ischemic stroke & Endocarditis & Blood culture & PCR & $\begin{array}{l}\text { Gentamicin and } \\
\text { Vancomycin }\end{array}$ \\
\hline $\begin{array}{l}\text { 2012, India } \\
{[12]}\end{array}$ & $M / 35 Y$ & $\begin{array}{l}\text { Rheumatic heart } \\
\text { disease }\end{array}$ & Endocarditis & Blood culture & Vitek ${ }^{\circledR} 2$ system & $\begin{array}{l}\text { Ceftriaxone } \\
\text { Gentamicin }\end{array}$ \\
\hline $\begin{array}{l}\text { 2014, Spain } \\
\text { [5] }\end{array}$ & $F / 81 Y$ & Obesity & $\begin{array}{l}\text { Prosthetic joint } \\
\text { infection }\end{array}$ & $\begin{array}{l}\text { Periprosthetic femo- } \\
\text { ral Prosthetic } \\
\text { tissue, femoral } \\
\text { interface membrane, } \\
\text { acetabular interface } \\
\text { membrane }\end{array}$ & Vitek ${ }^{\circledR} 2$ system & $\begin{array}{l}\text { Amoxicillin } \\
\text { Ceftriaxone }\end{array}$ \\
\hline $\begin{array}{l}\text { 2015, France } \\
{[16]}\end{array}$ & $F / 40 Y$ & None & Scapular abscess & Abscess culture & MALDI-TOF & Pristinamycine \\
\hline $\begin{array}{l}\text { 2015, USA } \\
{[13]}\end{array}$ & $F / 41 Y$ & Recurrent sinusitis & Meningitis & CSF culture & Vitek ${ }^{\circledR} 2$ system & Ceftriaxone \\
\hline $\begin{array}{l}\text { 2017, Germany } \\
{[17]}\end{array}$ & M/63Y & Melanoma & Thoracic abscess & Abscess culture & PCR & Clindamycin \\
\hline $\begin{array}{l}\text { 2019, Spain } \\
{[18]}\end{array}$ & $M / 9 Y$ & $\begin{array}{l}\text { Phimosis + balano- } \\
\text { preputial adhesions }\end{array}$ & Balanoposthitis & $\begin{array}{l}\text { Urethral exudate } \\
\text { culture }\end{array}$ & MALDI-TOF & $\begin{array}{l}\text { Amoxicillin and clavu- } \\
\text { lanic acid }\end{array}$ \\
\hline $\begin{array}{l}\text { 2019, Korea } \\
{[19]}\end{array}$ & $M / 67 Y$ & $\begin{array}{l}\text { Hepatitis B virus- } \\
\text { cirrhosis }\end{array}$ & Epidermal cyst & $\begin{array}{l}\text { Wound secretion } \\
\text { culture }\end{array}$ & Vitek ${ }^{\circledR} 2$ system & $\begin{array}{l}\text { Amoxicillin and clavu- } \\
\text { lanic acid }\end{array}$ \\
\hline $\begin{array}{l}\text { 2020, Switzerland } \\
\text { [14] }\end{array}$ & $\mathrm{M} / 75 \mathrm{Y}$ & $\begin{array}{l}\text { Benign prostatic } \\
\text { hyperplasia + tran- } \\
\text { surethral prostate } \\
\text { resection }\end{array}$ & Urosepsis & Urine culture & RAST (vClassic RAST) & $\begin{array}{l}\text { Ampicillin-Sulbactam } \\
\text { Vancomycin }\end{array}$ \\
\hline $\begin{array}{l}\text { 2020, France } \\
{[6]}\end{array}$ & $F / 57 Y$ & $\begin{array}{l}\text { Uterine myomatosis } \\
\text { and obesity }\end{array}$ & Peritonitis & Peritoneal culture & $\begin{array}{l}\text { MALDI-TOF Vitek } \\
\text { MS }^{\circledR}\end{array}$ & $\begin{array}{l}\text { Cefotaxime } \\
\text { Metronidazole } \\
\text { Amoxicillin }\end{array}$ \\
\hline $\begin{array}{l}\text { 2021, USA } \\
(20)\end{array}$ & $F / 64 Y$ & $\begin{array}{l}\text { Type } 2 \text { diabetes mel- } \\
\text { litus and coronary } \\
\text { artery disease }\end{array}$ & $\begin{array}{l}\text { Hidradenitis sup- } \\
\text { purativa }\end{array}$ & $\begin{array}{l}\text { Axillary abscess } \\
\text { culture }\end{array}$ & MALDI-TOF & $\begin{array}{l}\text { Moxifloxacin } \\
\text { Vancomycin } \\
\text { Trimethoprim/Sul- } \\
\text { famethoxazole }\end{array}$ \\
\hline 2021, Mexico & $F / 7 Y$ & $\begin{array}{l}\text { Congenital lym- } \\
\text { phangioma }\end{array}$ & Pyelonephritis & Urine culture & MALDI-TOF & Gentamicin \\
\hline
\end{tabular}

$M$ male, F female, CFS cerebrospinal fluid, PCR polymerase chain reaction, MALDI-TOF matrix-assisted laser desorption/ionization time-of-flight, ND no data

can be found in pairs, clusters, or chains, and on sheep blood agar colonies are non-pigmented and weakly alpha-hemolytic or non-hemolytic. Due to its resemblance in Gram-stain characteristics, colony morphology, hemolysis on $5 \%$ sheep blood agar, and catalase reaction, they may be misidentified as viridans-group Streptococci or discarded as contaminants $[3,7,8,10]$. Facklamia species can be recognized by their production of leucine aminopeptidase (LAP), L-pyrrolidonyl-beta-naphthylamide (PYR), and their ability to grow in $6.5 \%$ sodium chloride containing media [3-7].

Species of Facklamia have been identified using the API Rapid ID32 STREP system, API ZYM method, Vitek $^{\circledR} 2$ system (bioMerieux France), matrix-assisted laser desorption/ionization time-of-flight mass spectrometry (MALDI-TOF), and DNA sequence coding for $16 \mathrm{~S}$ RNA $[6,8,14]$ In the present case, Facklamia hominis was successfully identified by MALDI-TOF.

The distinction of Facklamia spp from viridans-group Streptococci and other Streptococcus-like organisms is clinically relevant because of its unusual susceptibility pattern. Susceptibility testing has been defined using the Clinical and Laboratory Standards Institute Guidelines for Streptococcus species other than Streptococcus pneumoniae. Physicians must be aware of the several limitations concerning Facklamia infections, as to date there is no standardized method of identification, or treatment guidelines available, and taking into account the inconsistency of susceptibility profiles reported, clinical decisions should be taken considering the susceptibility pattern of the isolate in question $[7,8]$. 
Outcomes of $F$. hominis infections are mostly encouraging when appropriate antibiotic therapy is warranted, such as the case we present [6].

\section{Conclusion}

This case is the second reported in a pediatric patient, the first reported in Latin America, and the first case of Facklamia hominis pyelonephritis in a child. Although this pathogen is an uncommon cause of infection, its identification and treatment remain a challenge for physicians. A variety of antibiotics have been used, including penicillin and third generation cephalosporins. In our case, the patient was successfully treated with gentamicin. Overall, our attestations point up that $F$. hominis is responsible of a variety of human infections and should be considered as an emerging pathogen, however there is scarce information of its virulence and pathogenic potential. This case illustrates the importance of appropriately identifying the bacteria and its susceptibility patterns, to prevent treatment failure and to avoid selective pressure on microbiota, thus preventing antimicrobial resistance.

\section{Abbreviations}

API: Analytical Profile Index; CBC: Complete blood count; CFU: Colony-forming unit; DNA: Deoxyribonucleic acid; LAP: Leucine aminopeptidase; MALDI-TOF: Matrix-assisted laser desorption/ionization time-of-flight; PYR: L-pyrrolidonyl-beta-naphthylamide; RNA: Ribonucleic acid.

\section{Acknowledgements}

Thanks to the Radiology Department, Microbiology Department and Bacteriology Laboratory of Hospital Universitario "José Eleuterio González" for their special contribution.

\section{Authors' contributions}

JIC-B \& DNV-A coordination; SP-C \& DC-S analysis and writing; AM-DS conception and coordination; FE- $V$ design of the work; HS-A identification in laboratory. All authors read and approved the final manuscript.

\section{Funding}

This research did not receive any specific Grant from funding agencies in the public, commercial, or not-for-profit sectors.

\section{Availability of data and materials}

Not applicable.

\section{Declarations}

Ethics approval and consent to participate

Not applicable.

\section{Consent for publication}

Written informed consent for publication of clinical details and clinical images was obtained from the parents of the patient. A copy of the consent form is available for review by the editor of the journal.

\section{Competing interests}

The authors declare that they have no competing interests.

\section{Author details}

${ }^{1}$ Department of Pediatrics / Infectious Diseases Service, Hospital Universitario "Dr. José Eleuterio González" Universidad Autónoma de Nuevo León, Francisco I. Madero Avenue, Mitras Centro, ZC 64460 Monterrey, Mexico. ${ }^{2}$ Department of Clinical Pathology, Hospital Universitario "Dr. José Eleuterio González" Universidad Autónoma de Nuevo León, Francisco I. Madero Avenue, Mitras Centro, ZC 64460 Monterrey, Mexico.

Received: 7 August 2021 Accepted: 28 January 2022

Published online: 12 February 2022

\section{References}

1. Kline KA, Lewis AL. Gram-positive uropathogens, polymicrobial urinary tract infection, and the emerging microbiota of the urinary tract. Microbiol Spectr. 2016;4:2. https://doi.org/10.1128/microbiolspec. UTI-0012-2012

2. Morello W, La Scola C, Alberici I, Montini G. Acute pyelonephritis in children. Pediatr Nephrol. 2016;31(8):1253-65

3. Mostafa HH, Taffner SM, Wang J, Malek A, Hardy DJ, Pecora ND. Genome sequence of a facklamia hominis isolate from a patient with urosepsis. Microbiol Resour Announc. 2019;8(17):e00100-e119.

4. Collins MD, Falsen E, Lemozy J, Åkervall E, Sjödén B, Lawson PAY. Notes: phenotypic and phylogenetic characterization of some globicatella-like organisms from human sources: description of Facklamia hominis gen nov, sp nov. Int J Syst Evol Microbiol. 1997;47(3):880-2.

5. Corona PS, Haddad S, Andrés J, González-López JJ, Amat C, Flores X. Case report: first report of a prosthetic joint infection caused by Facklamia hominis. Diagn Microbiol Infect Dis. 2014;80(4):338-40.

6. Ait Tamlihat Y, Violette J, Labrousse J, Bregeaud D, Vincent J. Identification of Facklamia hominis in a Case of Stercoral Peritonitis: A Case Report and Review of the Literature. Infect Dis. 2020;4:138.

7. Rahmati E, Martin V, Wong D, Sattler F, Petterson J, Ward P, et al. Facklamia Species as an Underrecognized Pathogen. Open Forum Infectious Diseases. 2017:4:1. https://doi.org/10.1093/ofid/ofw272.

8. Hoyles L. The genus Facklamia. In: Lactic Acid Bacteria. John Wiley \& Sons, Ltd; 2014. p. 91-8. https://onlinelibrary.wiley.com/doi/abs/https://doi. org/10.1002/9781118655252.ch8

9. Doll EV, Staib L, Huptas C, Scherer S, Wenning M. Facklamia lactis sp. nov., isolated from raw milk. Int J Syst Evol Microbiol. 2021;71(7):004869.

10. Healy B, Beukenholt RW, Tuthill D, Ribeiro CD. Facklamia hominis causing chorioamnionitis and puerperal bacteraemia. J Infect. 2005;50(4):353-5.

11 Safavi S, Tufnell M, Bhalla A. Multi-territory ischaemic strokes and subacute bacterial endocarditis. BMJ Case Rep. 2010;2010:bcr0620092023.

12. Ananthakrishna R, Shankarappa RK, Jagadeesan N, Math RS, Karur S, Nanjappa MC. Infective endocarditis: a rare organism in an uncommon setting. Case Rep Infect Dis. 2012;2012:307852.

13. Parvataneni KC, Iyer S, Khatib R, Saravolatz LD. Facklamia Species and Streptococcus pneumoniae meningitis: a case report and review of the literature. Open Forum Infect Dis. 2015;2:2. https://doi.org/10.1093/ofid/ ofv029.

14. Gahl M, Stöckli T, Fahrner R. Facklamia hominis bacteremia after transurethral resection of the prostate: a case report. BMC Urol. 2020;20(1):192.

15. Husain S, Singh $N$. The impact of novel immunosuppressive agents on infections in organ transplant recipients and the interactions of these agents with antimicrobials. Clin Infect Dis. 2002;35(1):53-61.

16. Abat C, Garcia V, Rolain J-M. Facklamia hominis scapula abscess, Marseille France. New Microbes New Infections. 2016;1(9):13-4.

17. Schlipköter M, Grieser T, Forst H. Unusual complication following placement of an epidural catheter. Anaesthesist. 2017:66(7):506-10.

18. Goméz-Luque JM, Foronda-García-Hidalgo C, Gutiérrez-Fernández J. Balanopostitis por Facklamia hominis en Pediatría. Rev Esp Quimioter. 2019;32(3):278-80.

19. Kim TY, Jo J, Kim N, Park H, Roh EY, Yoon JH, et al. Facklamia hominis Isolated from a Wound: A Case Report and Review of the Literature. Ann Clin Microbiol. 2019;22(2):50-4.

20. Basal Y, Oommen J, Faraj U, Acho R, Aravapally A. Facklamia hominis in hidradenitis suppurativa. JAAD Case Rep. 2021;11:20-2.

\section{Publisher's Note}

Springer Nature remains neutral with regard to jurisdictional claims in published maps and institutional affiliations. 